\title{
Chemical Fruit Thinning of Vaccinium ashei Reade
}

\author{
Jose R. Cartagena ${ }^{1}$ and Frank B. Matta ${ }^{2}$ \\ Department of Horticulture, Mississippi State University, Mississippi State, MS 39762 \\ James M. Spiers ${ }^{3}$ \\ U.S. Department of Agriculture-Agricultural Research Service, Small Fruit Research Station, \\ Poplarville, $M S$
}

Additional index words. rabbiteye blueberry, fruit weight, fruit size

\begin{abstract}
The thinning potential of various chemicals sprayed on 'Tifblue' rabbiteye blueberry was examined in the greenhouse in 1990 and under field conditions in 1991 and 1992. In the greenhouse, BA concentrations ranging from 25 to $500 \mathrm{mg} \cdot \mathrm{liter}^{-1}$ and carbaryl concentrations ranging from 400 to $2100 \mathrm{mg} \cdot \mathrm{liter}^{-1}$ reduced fruit set when treatments were applied 16 days after corolla drop (ACD). GA reduced fruit set only at $50 \mathrm{mg}^{-1 i t e r}{ }^{-1}$ and NAA did not influence fruit set.

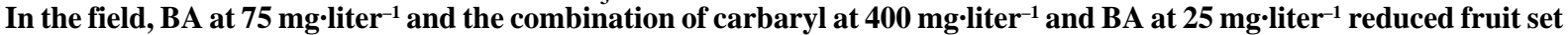
in 1991 and 1992. Combinations of carbaryl and $\mathrm{GA}_{3}$ reduced fruit set, but the response depended on GA $\mathrm{G}_{3}$ concentration and varied from year to year. GA, NAA, and carbaryl also reduced fruit set, but the results were inconsistent. In 1991,

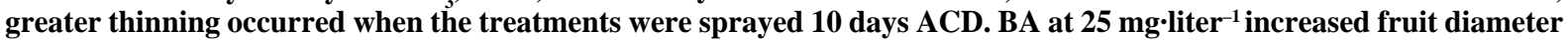
at first harvest in 1991, and carbaryl at $400 \mathrm{mg}^{-1 i t e r}{ }^{-1}$ increased fruit diameter in 1991 and 1992 . Fruit diameter was increased in the presence and absence of thinning, depending on year and application time. Yield and return bloom were not influenced by any of the treatments. Chemical names used: 7 benzylamino purine (BA); gibberellic acid (GA); 2naphaleneacetic acid (NAA); 1-naphthyl $N$-methylcarbamate (carbaryl).
\end{abstract}

Maintaining a balance between vegetative and reproductive growth is needed to optimize blueberry yield and quality. Selective removal of excess apples is achieved by chemical means (Knight, 1980; Knight and Spencer, 1987). Chemical fruit thinning may be a viable method for regulating blueberry crop load. However, no research has been reported on the use of chemical thinning for blueberries. The potential of BA as a thinning agent has been demonstrated by Kondo and Mizuno (1989), who showed that BA sprays increased ethylene evolution from apples, followed by increased fruit abscission. Gibberellins enhanced abscission of citrus (Lewis and Bakhshi, 1968) and other plants (Chatterje and Leopold, 1964). GA stimulated abscission of peach (Young and Edgerton, 1979) but did affect berry set in grapes (Looney and Wood, 1977). Thinning capabilities of NAA in apples are well documented (Williams, 1979). Fruit thinning has been associated with increased fruit size in peach (Byers, 1989), apples (Forshey and Elfving, 1977), and grapes (Reynolds et al., 1986). Fruit size of rabbiteye blueberries has been increased by pruning or selective cane removal (Austin and Brightwell, 1984). Mature highbush blueberries must be pruned annually to reduce overbearing (Galletta and Himelrick, 1990). Kaps and Cahoon (1989) reported that thinning grapes increased yield, and others found that thinning peach reduced yields substantially (Dozier et al., 1981). The objective of this study was to determine the effects of chemical thinning agents on blueberry thinning, yield, return bloom, and fruit size.

\footnotetext{
Received for publication 21 Oct. 1993. Accepted for publication 16 May 1994. Contribution of the Mississippi Agricultural and Forestry Experiment Station, Journal series no. J 8389. The cost of publishing this paper was defrayed in part by the payment of page charges. Under postal regulations, this paper therefore must be hereby marked advertisement solely to indicate this fact.

${ }^{1}$ Assistant professor. Current address: Institute Colombiano Agropecuario, Division Produccion de cultivos, seccion fruticola, Apartado Postal 40 Espinal, Tolima, Colombia.

${ }^{2}$ Professor.

${ }^{3}$ Research scientist.
}

\section{Materials and Methods}

Greenhouse experiment. In Spring 1990, chemical thinners were screened at Mississippi State Univ. $\left(33^{\circ} 27^{\prime} \mathrm{N}, 88^{\circ} 47^{\prime} \mathrm{W}\right)$ using uniform, mature, 'Tifblue' rabbiteye blueberry plants growing in 3-liter pots containing 1 peat : 1 vermiculite : 1 perlite (by volume). A randomized complete-block design with three singleplant replicates was used. Four limbs on each plant were tagged and apical flower buds counted before bloom. On 4 Mar., 16 days after corolla drop (ACD), the most terminal floral cluster on each limb was sprayed with the treatments listed in Table 1. The control consisted of distilled water, and each solution contained the surfactant $0.1 \%$ Tween 20 (polyoxyethylene sorbitan monolaurate) as a wetting agent. Effectiveness of the chemical thinners was determined 1 month after application and expressed as fruit set, with the initial count being $100 \%$. Fruit set percentages were adjusted using arcsin transformation before analysis. All treatments were analyzed with analysis of variance. Treatment means were compared using the $t$ test under SAS's least squares (LS) means option.

Field experiments. Two similar experiments were conducted using an 8-year-old 'Tifblue' rabbiteye blueberry research orchard at the U.S. Dept. of Agriculture Small Fruit Research Station, Poplarville, Miss. $\left(30^{\circ} 30^{\prime} \mathrm{N}, 89^{\circ} 87^{\prime} \mathrm{W}\right)$, during 1991 (12 Apr. to 11 July ) and 1992 (14 Apr. to 13 June). Plants were $2 \mathrm{~m}$ high and uniform in size and vigor. Plants were spaced and the orchard was managed according to commercial recommendations for Mississippi (Spiers et al., 1985). Concentrations of chemical thinners that showed a selective thinning of $30 \%$ to $69 \%$ in the greenhouse experiment were selected (Table 2). All solutions, including the distilled water control, contained the surfactant Tween 20 at $0.1 \%$. Foliar sprays were applied with an electrical pressure sprayer to runoff $\left(2.11 \mathrm{~kg} \cdot \mathrm{cm}^{-2}\right)$ to individual plants between 1100 and 1500 HR (Central Standard Time). Four branches on each plant were randomly selected to determine fruit thinning. In 1991, plants were sprayed either on $12 \mathrm{Apr}$., 10 days ACD when the average fruit diameter was $5.2 \mathrm{~mm}$ and air temperature was $26 \mathrm{C}$, or $23 \mathrm{Apr}$., 20 days ACD when the average fruit diameter was $8.5 \mathrm{~mm}$ and air 
Table 1. Fruit set percentage of 'Tifblue' blueberry as affected by chemical thinners applied 16 days after corolla drop (ACD), greenhouse experiment, 1991.

\begin{tabular}{|c|c|c|}
\hline Chemical & Concn (mg.liter $\left.{ }^{-1}\right)$ & Fruit set $(\%)$ \\
\hline \multirow[t]{9}{*}{$\overline{\mathrm{BA}}$} & 0 & $88.9 h^{2}$ \\
\hline & 25 & $39.7 \mathrm{a}-\mathrm{g}$ \\
\hline & 50 & $23.3 \mathrm{a}-\mathrm{d}$ \\
\hline & 75 & $43.2 \mathrm{a}-\mathrm{g}$ \\
\hline & 100 & $27.8 \mathrm{a}-\mathrm{e}$ \\
\hline & 150 & $42.2 \mathrm{a}-\mathrm{g}$ \\
\hline & 200 & $7.1 \mathrm{a}-\mathrm{b}$ \\
\hline & 250 & $0 \mathrm{a}$ \\
\hline & 500 & $23.8 \mathrm{a}-\mathrm{d}$ \\
\hline \multirow[t]{6}{*}{$\mathrm{GA}_{3}$} & 0 & $88.9 \mathrm{~h}$ \\
\hline & 25 & $66.5 \mathrm{~d}-\mathrm{h}$ \\
\hline & 50 & $38.1 \mathrm{a}-\mathrm{f}$ \\
\hline & 75 & $71.4 \mathrm{e}-\mathrm{h}$ \\
\hline & 100 & $80.3 \mathrm{~g}-\mathrm{h}$ \\
\hline & 150 & $74.5 \mathrm{f}-\mathrm{h}$ \\
\hline \multirow[t]{5}{*}{ NAA } & 0 & $88.9 \mathrm{~h}$ \\
\hline & 7.5 & $55.4 \mathrm{c}-\mathrm{h}$ \\
\hline & 15 & $52.7 \mathrm{~b}-\mathrm{h}$ \\
\hline & 30 & $76.6 \mathrm{f}-\mathrm{h}$ \\
\hline & 60 & $70.5 \mathrm{e}-\mathrm{h}$ \\
\hline \multirow[t]{8}{*}{ Carbaryl } & 0 & $88.9 \mathrm{~h}$ \\
\hline & 400 & $40.0 \mathrm{a}-\mathrm{g}$ \\
\hline & 600 & $31.0 \mathrm{a}-\mathrm{f}$ \\
\hline & 800 & $7.1 \mathrm{a}-\mathrm{b}$ \\
\hline & 1000 & $28.0 \mathrm{a}-\mathrm{e}$ \\
\hline & 1200 & $15.7 \mathrm{a}-\mathrm{c}$ \\
\hline & 1400 & $33.3 \mathrm{a}-\mathrm{f}$ \\
\hline & 2100 & $33.4 \mathrm{a}-\mathrm{f}$ \\
\hline
\end{tabular}

${ }^{\mathrm{z}}$ Mean separation within columns using $t$ test under SAS's least squares means option. Means with the same letters do not differ at $P=0.05$.

Table 2. Fruit set percentage of 'Tifblue' blueberry plants as affected by various thinning chemicals applied 10 or 20 days after corolla drop (ACD), 1991 and 1992.

\begin{tabular}{|c|c|c|c|}
\hline \multirow[b]{3}{*}{ Chemical } & \multirow{3}{*}{$\begin{array}{c}\text { Concn } \\
\left(\mathrm{mg} \cdot \text { liter }^{-1}\right)\end{array}$} & \multicolumn{2}{|c|}{ Fruit set (\%) } \\
\hline & & \multicolumn{2}{|c|}{ Year } \\
\hline & & 1991 & 1992 \\
\hline Control & & $76 d^{2}$ & $96.6 \mathrm{gf}$ \\
\hline \multirow[t]{2}{*}{ BA } & 25 & $64.9 \mathrm{bcd}$ & $86.6 \mathrm{cb}$ \\
\hline & 75 & $38.7 \mathrm{a}$ & $77.1 \mathrm{ba}$ \\
\hline \multirow{2}{*}{$\mathrm{GA}_{3}$} & 25 & $74.2 \mathrm{~d}$ & $78.0 \mathrm{ba}$ \\
\hline & 50 & $73.1 \mathrm{~cd}$ & $95.5 \mathrm{gf}$ \\
\hline \multirow[t]{2}{*}{ NAA } & 7.5 & $68.7 \mathrm{bcd}$ & $97.2 \mathrm{gf}$ \\
\hline & 15.0 & $69.6 \mathrm{bcd}$ & $90.8 \mathrm{e} \mathrm{d}$ \\
\hline \multirow[t]{2}{*}{ Carbaryl } & 400 & $68.8 \mathrm{bcd}$ & $92.4 \mathrm{ed}$ \\
\hline & 600 & $66.1 \mathrm{bcd}$ & 90.3 decd \\
\hline \multirow[t]{2}{*}{ Carbaryl + BA } & $400+25$ & $54.7 \mathrm{abc}$ & 87.4 dcbe \\
\hline & $400+75$ & $63.9 \mathrm{bcd}$ & $96.3 \mathrm{~g} \mathrm{f}$ \\
\hline \multirow[t]{2}{*}{ Carbaryl $+\mathrm{GA}_{3}$} & $400+25$ & $71.2 \mathrm{~cd}$ & $92.9 \mathrm{ed}$ \\
\hline & $400+50$ & $51.7 \mathrm{~b}$ & $98.0 \mathrm{gf}$ \\
\hline
\end{tabular}

${ }^{\mathrm{z}}$ Mean separation within columns were compared using the $t$ test under SAS's least squares means option. Means in columns with the same letter do not differ at $P=0.05$.

temperature was 24C. In 1992, applications were made either on 14 Apr., 10 days ACD when the average fruit diameter was $5.4 \mathrm{~mm}$ and air temperature was 29C, or on 23 Apr., 19 days ACD when average fruit diameter was $8.6 \mathrm{~mm}$ and air temperature was $26 \mathrm{C}$. Spray dates were calm and either partly cloudy (1991) or sunny (1992), and drift to nontreated plants was avoided by shielding individual plants with a tarp.

Thinning response was based on fruit counts of the first three terminal clusters on individual tagged limbs after fruit drop had ceased and expressed as percentage fruit set, with the initial count being $100 \%$. Fruit set percentages for both experiments were adjusted using arcsin transformation before analysis. Completely randomized designs were used in both years. All experimental units were single plants, and treatments were replicated four times. A factorial analysis of variance was performed, where chemical concentrations and application dates were the factors considered. Treatment means were compared using the $t$ test under SAS's LS means option.

In 1991 and 1992, to measure fruit diameter, a random ripe (blue) 500-g berry sample from the whole plant was harvested at two dates. To measure return bloom in 1992, the number of flower buds on new year's growth of three randomly selected limbs was counted. Yield was based on total berry weight per plant, and the plants were harvested twice.

\section{Results and Discussion}

Greenhouse study, 1990. All concentrations of BA and carbaryl reduced fruit set. $\mathrm{GA}_{3}$ reduced fruit set only at $50 \mathrm{mg} \cdot \mathrm{liter}^{-1}$. NAA did not influence fruit set (Table 1). Treatments that resulted in fruit set of $70 \%$ to $31 \%$ were selected for field investigations.

Field study. The factorial analysis showed no interaction between chemicals and application dates; therefore, only main effect means for each year were considered (Table 2). BA at 75 mg.liter ${ }^{-1}$ reduced fruit set in 1991 and 1992. BA at $25 \mathrm{mg} \cdot \mathrm{liter}^{-1}$ also reduced fruit set in 1992 . The combination of carbaryl at 400 $\mathrm{mg} \cdot$ liter $^{-1}$ and BA at $25 \mathrm{mg} \cdot$ liter $^{-1}$ reduced fruit set in 1991 and 1992. The consistent reduction in fruit set with BA and lack of response to carbaryl in 1991 suggest that BA was primarily responsible for reduced fruit set. The combination of carbaryl and $\mathrm{GA}_{3}$ reduced fruit set; however, its effectiveness depended on $\mathrm{GA}_{3}$ concentration and varied from year to year. $\mathrm{GA}_{3}, \mathrm{NAA}$, and carbaryl did not influence fruit set in 1991; however, in 1992, these chemicals reduced fruit set; $\mathrm{GA}_{3}$ was effective at $25 \mathrm{mg} \cdot \mathrm{liter}^{-1}$, NAA was effective at $15 \mathrm{ppm}$, and carbaryl was effective at both concentrations. The lack of consistent response to $\mathrm{GA}_{3}$, NAA, and carbaryl from year to year makes the role of these compound in blueberry thinning difficult to interpret. Rogers and Thompson (1983) raised the possibility that this erratic response may be due to biological and meteorological variations. Analysis of variance also indicated that application date was significant in 1991, showing greater thinning when the treatments were sprayed 10 days after corolla drop (ACD); however, in 1992, application date was not significant. In addition, fruit set was greater in 1992. Lack of absorption due to chemical volatility or plant vigor may have been factors.

Yield in 1991 and 1992 and return bloom in 1992 were not influenced by thinning treatments (data not shown). BA has enhanced flower bud formation in apple, especially when applied soon after bloom (McLaughlin and Greene, 1984). In this study, $\mathrm{BA}$ or $\mathrm{GA}_{3}$ did not increase return bloom. However, increased return bloom on apples is due to elimination of fruit that are a source of gibberellins early in the season. Return bloom on blueberries is associated with shoot vigor (Gough and Shutak, 1978) and thickness of 1-year-old wood (Gough et al., 1976), both of which are secondary effects influenced by crop load. 
Table 3. Fruit diameter at first harvest of 'Tifblue' blueberry plants as affected by chemical thinners and application date, 10 or 20 days after corolla drop (ACD), 1991 and 1992.

\begin{tabular}{|c|c|c|c|c|c|}
\hline \multirow[b]{5}{*}{ Chemical } & \multirow{5}{*}{$\begin{array}{c}\text { Concn } \\
\left(\mathrm{mg} \cdot \text { liter }^{-1}\right)\end{array}$} & \multicolumn{4}{|c|}{ Fruit diam (mm) } \\
\hline & & \multicolumn{4}{|c|}{ Year } \\
\hline & & \multicolumn{2}{|c|}{1991} & \multicolumn{2}{|c|}{1992} \\
\hline & & \multicolumn{4}{|c|}{ Application date } \\
\hline & & $10 \mathrm{ACD}$ & $20 \mathrm{ACD}$ & $10 \mathrm{ACD}$ & $20 \mathrm{ACD}$ \\
\hline$\overline{\text { Control }}$ & & $14.1^{\mathrm{z}}$ Ade & 14.9 Aabc & 16.3 Abcd & $16.0 \mathrm{Abc}$ \\
\hline \multirow[t]{2}{*}{ BA } & 25 & 15.6 Aab & 14.2 Bbc & 16.2 Bcd & 16.6 Aabc \\
\hline & 75 & 14.4 Acde & 14.5 Aabc & $15.9 \mathrm{Bd}$ & $17.0 \mathrm{Aa}$ \\
\hline \multirow[t]{2}{*}{$\mathrm{GA}_{3}$} & 25 & 14.4 Acde & 14.1 Abc & 16.7 Aa-d & 16.3 Aabc \\
\hline & 50 & $14.7 \mathrm{Ab}-\mathrm{e}$ & 14.4 Aabc & $16.4 \mathrm{Ba}-\mathrm{d}$ & 16.9 Aab \\
\hline \multirow[t]{2}{*}{ NAA } & 7.5 & $14.8 \mathrm{Ab}-\mathrm{e}$ & 15.3 Aab & 16.6 Aa-d & 16.8 Aabc \\
\hline & 15 & 15.1 Aa-d & 15.2 Aabc & 16.4 Aa-d & 16.1 Aabc \\
\hline \multirow[t]{2}{*}{ Carbaryl } & 400 & 15.3 Aabc & 15.1 Aabc & 17.1 Aa & $16.0 \mathrm{Bc}$ \\
\hline & 600 & $15.9 \mathrm{Aa}$ & $13.9 \mathrm{Bc}$ & 16.7 Aabc & 16.3 Aabc \\
\hline \multirow[t]{2}{*}{ Carbaryl + BA } & $400+25$ & $13.9 \mathrm{Be}$ & 14.7 Aabc & 16.6 Aa-d & 16.8 Aabc \\
\hline & $400+75$ & 14.6 Bcde & $15.5 \mathrm{Aa}$ & 16.2 Acd & 16.4 Aabc \\
\hline \multirow[t]{2}{*}{ Carbaryl $+\mathrm{GA}_{3}$} & $400+25$ & 14.5 Acde & 14.5 Aabc & 16.3 Bbcd & 16.8 Aabc \\
\hline & $400+50$ & 14.2 Ade & 14.8 Aabc & 17.0 Aab & 16.5 Babc \\
\hline
\end{tabular}

$\overline{\mathrm{z}}$ Mean separation within columns and rows compared using the $t$ test under SAS's least squares means option. Means in columns with the same small letter and means in rows with the same capital letter do not differ at $P=0.05$. Means represent average diameter of 10 blueberries.

Table 4. Fruit diameter at second harvest of 'Tifblue' blueberry plants as affected by chemical thinners and application date, 10 or 20 days after corolla drop (ACD), 1992.

\begin{tabular}{|c|c|c|c|}
\hline \multirow[b]{3}{*}{ Chemical } & \multirow{3}{*}{$\begin{array}{c}\text { Concn } \\
\left(\mathrm{mg} \cdot \text { liter }^{-1}\right)\end{array}$} & \multicolumn{2}{|c|}{ Fruit diam $(\mathrm{mm})$} \\
\hline & & \multicolumn{2}{|c|}{ Application date } \\
\hline & & $10 \mathrm{ACD}$ & $20 \mathrm{ACD}$ \\
\hline Control & & $14.4^{\mathrm{z}} \mathrm{Ab}$ & $14.1 \mathrm{Ad}^{\mathrm{y}}$ \\
\hline \multirow[t]{2}{*}{$\mathrm{BA}$} & 25 & $14.8 \mathrm{Aab}$ & 15.5 Aab \\
\hline & 75 & $14.3 \mathrm{Bb}$ & 15.4 Aabc \\
\hline \multirow{2}{*}{$\mathrm{GA}_{3}$} & 25 & $14.3 \mathrm{Bb}$ & $15.5 \mathrm{Aab}$ \\
\hline & 50 & $15.3 \mathrm{Aab}$ & $15.1 \mathrm{Aa}-\mathrm{d}$ \\
\hline \multirow[t]{2}{*}{ NAA } & 7.5 & $14.9 \mathrm{Bab}$ & $15.8 \mathrm{Aa}$ \\
\hline & 15 & 15.0 Aab & 14.3 Acd \\
\hline \multirow[t]{2}{*}{ Carbaryl } & 400 & 15.3 Aabc & 14.8 Aad \\
\hline & 600 & 15.1 Aab & 14.8 Aad \\
\hline \multirow[t]{2}{*}{ Carbaryl + BA } & $400+25$ & $15.0 \mathrm{Aab}$ & 14.7 Aad \\
\hline & $400+75$ & $14.8 \mathrm{Aab}$ & 14.4 A bcd \\
\hline \multirow[t]{2}{*}{ Carbaryl $+\mathrm{GA}_{3}$} & $400+25$ & $15.3 \mathrm{Aab}$ & 15.0 Aad \\
\hline & $400+50$ & $15.6 \mathrm{Aa}$ & 14.3 Bbcd \\
\hline
\end{tabular}

${ }^{\mathrm{z}}$ Mean separation within columns and rows compared using the $t$ test under SAS's least squares means option. Means in columns with the same small letter and means in rows with the same capital letter do not differ at $P=0.05$. Means represent average diameter of 10 blueberries.

Thinning results with $\mathrm{GA}_{3}$ in 1992 agree with Looney (1981), who reported grape thinning using $\mathrm{GA}_{3}$. However, $\mathrm{GA}_{3}$ is sold specifically for increasing fruit set in blueberries. The recommended $\mathrm{GA}_{3}$ application time is when most flowers are elongated but not yet open. In this study, $\mathrm{GA}_{3}$ was applied postbloom when the ovaries were $5.2 \mathrm{~mm}$.

Analysis of variance for fruit diameter indicated that chemical concentrations and application date were significant and that there was an interaction of these factors in both years (Table 3). In 1991, application date made no difference in fruit diameter at first harvest except for BA at $25 \mathrm{mg} \cdot \mathrm{liter}^{-1}$ and carbaryl at $600 \mathrm{mg} \cdot \mathrm{liter}^{-1}$, which resulted in larger fruit when applied 10 days $\mathrm{ACD}$; conversely plants treated with carbaryl plus BA at both levels had larger fruit with the 20 ACD application date. In 1992, at first harvest, greater fruit diameter was obtained with carbaryl at $400 \mathrm{mg} \cdot \mathrm{liter}^{-1}$ when applied 10 vs. 20 days ACD and BA at both concentrations. GA at $50 \mathrm{mg} \cdot \mathrm{liter}^{-1}$ increased fruit diameter when applied $20 \mathrm{vs.} 10$ days ACD. In addition, the combination of carbaryl plus $\mathrm{GA}_{3}$ at 25 $\mathrm{mg} \cdot \mathrm{liter}^{-1}$ increased fruit diameter when applied $20 \mathrm{vs.} 10$ days ACD. However, carbaryl plus $\mathrm{GA}_{3}$ at $50 \mathrm{mg}$. liter $^{-1}$ increased fruit diameter when applied 10 vs. 20 days ACD (Table 3). At second harvest in 1992, BA at $75 \mathrm{mg} \cdot \mathrm{liter}^{-1}$, GA at $25 \mathrm{mg} \cdot \mathrm{liter}^{-1}$, and NAA at $7.5 \mathrm{mg} \cdot \mathrm{liter}^{-1}$ increased fruit diameter when applied 20 vs. 10 days ACD, and the combination of carbaryl plus $\mathrm{GA}_{3}$ at 50 $\mathrm{mg} \cdot \mathrm{liter}^{-1}$ increased fruit diameter when applied $10 \mathrm{vs.} 20$ days ACD (Table 4).

In 1991, fruit diameter at first harvest was increased by BA at $25 \mathrm{mg} \cdot$ liter $^{-1}$ and carbaryl at both concentrations when applied 10 but not 20 days ACD. These treatments did not reduce fruit set in 1991; therefore, the increase in fruit size was not due to thinning. Apparently BA and carbaryl directly influenced fruit diameter. Greene and Lord (1985) found an increase in apple size in the absence of thinning when $\mathrm{GA}_{4+7}$ plus BA was used. Fruit diameter was not influenced by any of the treatments when applied 20 days ACD in 1991 compared to the control. In 1992, only carbaryl at 400 $\mathrm{mg} \cdot$ liter $^{-1}$ and BA at $75 \mathrm{mg} \cdot$ liter $^{-1}$ increased fruit diameter when applied 10 and 20 days ACD, respectively. Since BA and carbaryl reduced fruit set in 1992, the increase in fruit diameter in 1992 may be attributed to thinning. It is evident that, in both years, carbaryl at $400 \mathrm{mg} \cdot \mathrm{liter}^{-1}$ increased fruit diameter at first harvest when treatments were applied 10 days ACD (Table 3 ).

In 1992, at second harvest, only the combination of carbaryl at $400 \mathrm{mg} \cdot \mathrm{liter}^{-1}$ and $\mathrm{GA}_{3}$ at $50 \mathrm{mg} \cdot \mathrm{liter}^{-1}$, which did not reduce fruit set in 1992, increased fruit diameter when applied 10 but not 20 days ACD; therefore, the increase in fruit size cannot be attributed to increased thinning (reduced fruit set). When the treatments were applied 20 days ACD in 1992, BA, regardless of concentration,

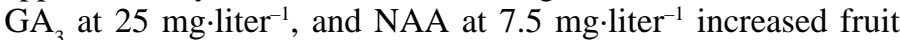
diameter. The continued increase in fruit size with $\mathrm{BA}$ and $\mathrm{GA}_{3}$ at 
second harvest in 1992 may be attributed to fruit thinning, since BA and $\mathrm{GA}_{3}$ reduced fruit set in 1992. However, increased fruit diameter by NAA at $7.5 \mathrm{mg} \cdot$ liter $^{-1}$ at second harvest in 1992 cannot be attributed to fruit thinning, since NAA at $7.5 \mathrm{mg} \cdot$ liter $^{-1}$ did not reduce fruit set in 1992. NAA has increased fruit size in the absence of thinning (Rogers and Thompson, 1983). Blueberry fruit size has been correlated with shoot vigor. Generally, more vigorous shoots produce larger berries (Galletta and Himelrick, 1990). Treatments in this experiment would not be expected to influence plant vigor and, therefore, not influence fruit size. Also, Shutak et al. (1980) reported that blueberry fruit enlargement follows a double sigmoid growth curve. In Stage I, the fruit undergoes rapid pericarp development with cell division and accelerated endosperm growth. It is possible that BA and carbaryl directly influenced cell division. Apparently, the treatments that resulted in fruit thinning did not influence berry cell division or mesocarp enlargement, which occur in Stage III.

Results from this study indicate that BA alone or combined with carbaryl consistently thinned 'Tifblue' rabbiteye blueberries. Fruit diameter increase by BA and carbaryl seemed to influence berry growth directly, although fruit diameter was also increased in the presence of thinning. $\mathrm{GA}_{3}$, NAA, and carbaryl gave inconsistent thinning results. Increased fruit diameter by NAA and the combination of carbaryl and $\mathrm{GA}_{3}$ occurred only in 1992 in the absence of thinning. There was a concentration $\times$ application date interaction, indicating fruit diameter depended on concentration and application date. In both years, however, carbaryl at 400 $\mathrm{mg} \cdot$ liter $^{-1}$ increased fruit diameter when applied 10 days ACD but decreased fruit set only in 1992. Yield and return bloom were not influenced by any of the chemical thinners. Further research on blueberry chemical fruit thinning is needed to determine cultivar differences and the influence of environmental conditions, application method, and multiple applications of thinners. The influence of such thinners on fruit size must be investigated.

\section{Literature Cited}

Abbott Laboratories. 1993. ProGibb for blueberries. Tech. Bul. AG 4855. Austin, M.E. and W.T. Brightwell. 1984. Rejuvenating rabbiteye blueberry 'Tifblue' and 'Woodard'. J. Amer. Soc. Hort. Sci. 109:74-77.

Byers, R.E. 1989. Response of peach trees to bloom thinning. Acta. Hort. 254:125-132.

Chatterjee, S.K. and A.C. Leopold. 1964. Kinetin and gibberellin abscission in cotton. Plant Physiol. 39:334-337.

Dozier, W.A., C.C. Carlton, K.C. Short, and J.A. McGuire. 1981. Thinning 'Loring' peaches with CGA 15281. HortScience 16:56-57.

Forshey, C.G. and D.C. Elfving. 1977. Fruit numbers, fruit size, and yield relationships in McIntosh' apples. J. Amer. Soc. Hort. Sci. 102:399_ 402.

Galletta, G.J. and D.G. Himelrick, 1990. Small fruit crop management. Prentice Hall, Englewood Cliffs, N.J.

Gough, R.E., and V.G. Shutak. 1978. Anatomy and morphology of cultivated highbrush blueberry. Rhode Island Agr. Expt. Sta. Bul. 423.

Gough, R.E., V.G. Shutak, and N.D. Windus. 1976. Observations on the vegetative and reproductive growth of the cultivated highbush blueberry. HortScience 11:260-261.

Greene, D.W. and W.J. Lord. 1985. Effect of chemical thinners on 'Delicious' apple trees previously sprayed with $\mathrm{GA}_{4+7}$ and BA. HortScience 20:84-86.

Kaps, M.L. and G.A. Cahoon. 1989. Berry thinning and cluster thinning influence vegetative grower, yield, fruit composition and net photosynthesis of 'Seyval blanc' grapes. J. Amer. Soc. Hort. Sci. 114:20-24.

Knight, J.N. 1980. Fruit thinning of the apple cultivar Cox's orange pippin. J. Hort. Sci. 55:267-273.

Knight, J.N. and J.E. Spencer. 1987. Timing of application of carbaryl used as an apple fruitlet thinner. J. Hort. Sci. 62:11-16.

Kondo, S. and N. Mizuno. 1989. Relation between early drop of apple fruit and endogenous growth regulators, and effects of MCPB, $\mathrm{GA}_{3}$ plus $\mathrm{GA}_{4}$ and BA sprays on fruit abscission. J. Jpn. Soc. Hort. Sci. 58:9-16.

Lewis, L.N. and N.C. Bakhshi. 1968. Protein synthesis in abscission: The distinctiveness of the abscission zone and its response to gibberellic acid and indoleacetic acid. Plant Physiol. 43:359-364.

Looney, N.E. 1981. Some growth regulator and cluster thinning effects on berry set and size, berry quality, and annual productivity of 'Dechaunac' grapes. Vitis 20:22-35.

Looney, N.E. and D.F. Wood. 1977. Some cluster thinning and gibberellic acid effects on fruit set, berry size, vine growth and yield of Dechaunac grapes. Can. J. Plant Sci. 57:653-659.

McLaughlin, J.M. and D.W. Greene. 1984. Effects of BA, GA ${ }_{4+7}$, and daminozide on fruit set, fruit quality, vegetative growth, flower initiation, and flower quality of 'Golden Delicious' apple. J. Amer. Soc. Hort. Sci. 109:34-39.

Reynolds, A.G., R.M. Pool, and L.P. Mattick. 1986. Effect of shoot density and crop control on growth, yield, fruit composition, and wine quality of 'Seyval blanc' grapes. J. Amer. Soc. Hort. Sci. 111:55-63.

Rogers, B.L. and A.H. Thompson. 1983. Effects of dilute and concentrated sprays of NAA and carbaryl in combination with daminozide and pesticides on fruit size and return bloom of 'Starkrimson Delicious' apple. HortScience 18:61-63.

Spiers, J.M., J.M. Braswell, and C.P. Hegwood, Jr. 1985. Establishment of rabbiteye blueberries. Mississippi Agr. and For. Expt. Sta. Bul. 941.

Shutak, V.G., R.E. Gough, and N.D. Windus. 1980. The cultivated highbush blueberry: Twenty years of research. Rhode Island Agr. Expt. Sta. Bul. 428.

Williams, M.W. 1979. Chemical thinning apples. Hort. Rev. 1:270-298. Young, E. and L.J. Edgerton. 1979. Effects of ethephon and gibberellic acid on thinning peaches. HortScience 14:713-714. 